\title{
Does IT Integration Really Enhance Supplier Responsiveness In Global Supply Chains?
}

\author{
Rudolf R. Sinkovics • Ruey-Jer 'Bryan' Jean • Anthony S. Roath • \\ S. Tamer Cavusgil
}

\section{Abstract}

- In order to enhance local suppliers' responsiveness in global supply chain relationships, MNEs must work with their local suppliers to create new form of relationship structures. Cultural and country differences may limit the use and effectiveness of traditional tools that govern the relationships between MNE and their local suppliers.

- Drawing on the resource-based view and transaction cost economics, this study uses 219 Taiwanese electronics suppliers to examine the influence of information technology integration and trust on supply chain responsiveness in varied cultural distance conditions. We find that the process is mediated by certain governance mechanisms including cooperativeness efforts and MNEs control.

- This study demonstrates that the use of IT integration through B2B information technology and trust can help MNEs enhance local suppliers' responsiveness in global supply chain relationships.

\section{Key Words}

Information technology, trust, global supply chain relationships, cooperativeness, control, supplier responsiveness

\section{Authors}

Rudolf R. Sinkovics

Manchester Business School, UK

(e-mail: Rudolf.Sinkovics@manchester.ac.uk)

Ruey-Jer 'Bryan' Jean $(\bowtie)$

National Chengchi University, Taiwan

(e-mail: bryan@nccu.edu.tw)

Anthony S. Roath

University of Oklahoma, USA

(e-mail: asroath@ou.edu)

S. Tamer Cavusgil

Georgia State University, USA

(email: stcavusgil@gsu.edu)

Manuscript Submitted: 20 Nov 2009, Revised: 17 Jun 2010, Accepted: 30 Jul 2010

This is a pre-print (non-publisher's document). Please cite the published article:

Sinkovics, Rudolf R., Ruey-Jer 'Bryan’ Jean, Anthony S. Roath, and S. Tamer Cavusgil (2011), "Does it integration really enhance supplier responsiveness in global supply chains?," Management International Review, 51 (2), 193-212. (DOI: 10.1007/s11575-0110069-0). 


\section{Does IT Integration Really Enhance Supplier Responsiveness In Global Supply Chains?}

\section{Rudolf R. Sinkovics • Ruey-Jer 'Bryan' Jean • Anthony S. Roath • S. Tamer Cavusgil}

\section{Abstract}

- In order to enhance local suppliers' responsiveness in global supply chain relationships, MNEs must work with their local suppliers to create new forms of relationship structures. Cultural and country differences may limit the use and effectiveness of traditional tools that govern the relationships between MNE and their local suppliers.

- Drawing on the resource-based view and transaction cost economics, this study uses 219 Taiwanese electronics suppliers to examine the influence of information technology integration and trust on supply chain responsiveness in varied cultural distance conditions. We find that the process is mediated by a governance mechanism including cooperativeness efforts and MNEs control.

- This study demonstrates that the use of IT integration through B2B information technology and trust can help MNEs to enhance local suppliers' responsiveness in global supply chain relationships.

\section{Key Words}

Information technology, trust, global supply chain relationships, cooperativeness, control, supplier responsiveness

\section{Authors}

Rudolf R. Sinkovics

Manchester Business School, UK

(e-mail: Rudolf.Sinkovics@manchester.ac.uk)

Ruey-Jer 'Bryan' Jean $(\bowtie)$ [corresponding author]

National Chengchi University, Taiwan

(e-mail: bryan@nccu.edu.tw)

Anthony S. Roath

University of Oklahoma, USA

(e-mail: asroath@,ou.edu)

\section{S. Tamer Cavusgil}

Georgia State University, USA

(email: stcavusgil@gsu.edu)

Manuscript Submitted: 20 Nov 2009, Revised: 17 Jun 2010, Accepted: 30 Jul 2010 


\section{Does IT Integration Really Enhance Supplier Responsiveness In Global Supply Chains?}

\section{Introduction and motivation}

Globalization has triggered significantly structural change for the strategy of multinational enterprises (MNEs). With increasing global competition, MNEs have disintegrated their value-adding activities with their suppliers or subcontractors around the world (Buckley and Ghauri 2004). Driven by this mega trend, the manner in which MNEs effectively coordinate and control their global supply chain relationships with local suppliers becomes a critical task to enhance their competiveness.

Supply chain responsiveness has become one of the most important performance metrics for managers in today's time-based competition era (Handfield and Bechtel 2002; Hult, Ketchen and Slater 2004). Industrial suppliers or subcontractors have been pushed to respond more quickly to their global supply chain customers' increasing demands. Despite the importance of supply chain responsiveness, the extant literature has not been explored the mechanism or process through which MNEs enhance their local supplier's responsiveness in their global supply chain relationships in (Hult, Ketchen and Slater 2004).

In the marketing channel literature, cooperativeness and control have been treated as two crucial interorganizational governance mechanisms (Luo et al. 2010). Cooperativeness was regarded as a bilateral form of governance and control was a unilateral form of governance. While some studies have identified the importance of cooperativeness and control in interfirm relationships, empirical evidence on antecedents and outcomes of cooperativeness and control in governing channel relationships has been limited, especially in the international context.

Trust has been identified as one of the most important cooperativeness mechanisms which can help structure interfirm relationships. However, trust alone is not sufficient to structure the interfirm relationships due to its weak ties of nature. It has been argued that advancement of Internet and business to business (B2B) technology can complement trust as an enabler for managing interfirm relationships (Jean 2007; Jean, Sinkovics and Kim 2008). B2B technologies and Internet provides IT integration between buyers and sellers and thus reduce cooperativeness and control cost in the interorganizational relationships (Wang, Tai and Wei 2006). Despite the importance of trust and IT integration, their roles as antecedents 
of different governance mechanism have not been fully examined. Moreover, although some studies already linked trust and IT integration to supplier responsiveness (Handfield and Bechtel 2002; Wang, Tai and Wei 2006), the process by which this occurs has not been explored in the extant literature.

This study seeks to examine how trust and IT integration can impact cooperativeness and control and ultimately lead to higher supplier responsiveness in global supply chain relationships between MNEs and their local suppliers. More specifically, this paper attempts to answer the following research questions:

1. To what extent do trust and IT integration influence cooperativeness and control in global supply chain relationships between MNEs and their suppliers?

2. To what extent does the MNE's use of cooperativeness and control impact on supplier's responsiveness in global supply chain relationships?

3. To what extent does cultural distance shape the process between trust, IT integration and different governance mechanisms including cooperativeness and control for MNEs with their suppliers?

This study attempts to contribute to the literature by addressing the role of trust and IT integration through B2B technology in enhancing governance mechanisms for MNEs in order to generate higher supplier responsiveness in global supply chain. The extant literature has discussed MNE's cooperativeness and control within MNE networks between headquarters and subsidiaries (e.g.Cray 1984). There has been limited literature which deals with the issue of cooperativeness and control in MNEs' global supply chain context. The other goal of this study is to investigate the effects of governance mechanisms including cooperativeness and control on supplier responsiveness. There has been limited empirical evidence to date that discusses the performance effects of different governance mechanisms on international supply chain relationships. Finally, this study also examined the moderation of cultural distance on governance mechanisms as empirical evidence has been limited in dealing with this issue.

The context in which we investigate this issue is from the perspective of upstream supply chain relationships, between MNE and their local subcontractors. The relationships between MNEs and their electronics subcontractor in Taiwan will be chosen for investigation. The survey methodology was conducted and structural equation modeling was employed to analyze the data.

The paper will be structured as follows: in the following conceptual framework, we 
define supply chain responsiveness and develop hypotheses relating trust and IT integration to governance mechanisms that ultimately lead to supply chain responsiveness. Moreover, we also develop hypotheses which address how cultural distance can influence the process of trust and IT integration on governance mechanism. We then describe an empirical study testing the framework and its hypotheses, report the findings, and discuss the implications for theory and managers. We conclude by outlining this study's limitation and areas for future research.

\section{Conceptual framework}

As shown in Figure 1, drawing from the resource-based view (Barney 1991) and transaction cost economics (TCE) (Williamson 1975) and following the emerging view of governance value analysis (Ghosh and John 1999), we propose that resources (trust and IT integration) in interorganizational relationships can influence firm's governance decision (cooperativeness and control) while simultaneously and ultimately stimulating supply chain responsiveness. We also highlight the notion that cultural distance between exchange partners can shape the process of trust and IT integration's influence on cooperativeness and control in global supply chain relationships.

Insert Figure 1 about here

\section{Responsiveness}

Supplier responsiveness, the ultimate outcome variable in this study, is defined as the extent to which suppliers' effectively marshal and redeploy resources to respond quickly to environmental changes (Handfield and Bechtel 2002; Wu et al. 2006). In the supply chain relationships, cycle time reduction has been regarded as one of the most important outcome variables (Hult, Ketchen and Arrfelt 2007; Hult, Ketchen and Slater 2004). Today's complicated and dynamic business environment requires suppliers to develop cycle timebased capability to deal with competitive and changing situation to satisfy demanding global customers. In parallel with dynamic capability theory, responsiveness can be one of the most important dynamic capabilities which help firms achieve greater competiveness ahead of competition in supply chain relationships. Researchers have demonstrated that higher supplier responsiveness is positively related to improved customer satisfaction (Handfield and Bechtel 
2002) and enhanced market performance (Kim, Cavusgil and Calantone 2006).

\section{Governance mechanisms}

Researchers have explored the governance mechanisms that exist between organizations (Heide 1994; Weitz and Jap 1995) and within organizations (Ouchi 1980). They identify two types of interorganizational governance mechanisms: the unilateral and the bilateral form of governance (Heide 1994). The distinction between unilateral and bilateral control mechanisms is based on whether the manufacturer and the supplier participate in making mutual decisions (Heide 1994). The unilateral form of governance is based on the controlling party's effort to influence its party's action. It is based on the use of external measurement, such as output measurement or the monitoring of a partner's behavior (Celly and Frazier 1996; Heide 1994). In contrast, the bilateral form of governance mechanism relies on relational norms which stimulate efforts for the mutual benefit of the manufacturer and the supplier (Lusch and Brown 1996; Weitz and Jap 1995). The literature shows that moderate unilateral governance combined with bilateral or relational based governance mechanisms are likely to govern exchange parties effectively as the organizations seek desired outcomes (Aulakh, Kotabe and Sahay 1996; Bello and Gilliland 1997; Ryu and Eyuboglu 2007). This study focuses on cooperativeness as a bilateral form of governance and control as a unilateral form of governance mechanism.

\section{Cooperativeness efforts}

Cooperativeness efforts here refer to the extent to which firms in the relationship are willing to work together to integrate, combine and deploy resources (Jap 1999; Wu et al. 2006). Although other studies include information exchange as a dimension of cooperativeness, this paper mainly focuses on the collaborative efforts of cooperativeness. These cooperativeness activities can range from joint meeting to product co-development between exchange partners.

Some studies have demonstrated that cooperativeness effort is an effective form of governance and a critical interorganizational resource which helps firms in collaborative interorganizational relationships to achieve competitive advantage (Jap 1999; Wu et al. 2006). However, cooperativeness has its problem as well. Close cooperativeness in interfirm relationships may cause too much embeddedness and could leave exchange parties vulnerable for external shocks (Song, Di Benedetto and Zhao 2008). Thus, it has been argued that simultaneous use of the bilateral and unilateral forms of governance are critical for 
successful interfirm relationship management (Ryu and Eyuboglu 2007).

\section{Vertical control}

Vertical control is a unilateral form of governance which refers to the extent to which a firm has control over another firm's key decision (Ryu and Eyuboglu 2007). In the supply chain relationships among manufacturers and their suppliers, vertical control involves constant review of a supplier's performance standard including product quality, delivery service and order fulfillment. Although both output and behavior aspects of control mechanisms have been discussed in the extant literature, we focus on output control as a vertical control mechanism because empirical evidence implies limited benefits of behavior control in business exchanges (Bello and Gilliland 1997; Heide, Wathne and Rokkan 2007). Studies have shown that appropriate control of supplier performance is critical for developing successful relationships with suppliers and can generate greater benefits. Vertical control, which signals the suppliers about their customers' vital performance goals, could enhance mutual understanding between exchange parties and thus deter opportunistic behaviors. For example, in a manufacturer-foreign distributor setting, Bello and Gilliland (1997) find that output control can enhance manufacture's export performance in international markets.

However, some studies also argue that vertical control may have a negative effect in governing interfirm relationships. Since vertical control involves one party's unilateral power over the other party in exchange relationships, it could offend supplier's sense of autonomy and increase their potential toward opportunistic behaviors in relationship (Heide, Wathne and Rokkan 2007). Therefore, it has been suggested that unilateral governance alone is not sufficient for successful interorganizational governance in channel relationships.

\section{Research hypotheses}

\section{The relationships between IT integration and governance mechanisms}

The advancement of Internet and B2B technology has changed and restructured interfirm relationships. IT integration refers to the extent to which firms conduct supply chain activities via virtual interconnectivenss through Internet and B2B technology with their exchange partners (Wang and Hsiao-Lan 2007; Wang, Tai and Wei 2006). These IT integrations involve activities ranging from online billing, checking ordering status, inventory levels etc. in supply chain relationships.

Recent studies have demonstrated that IT integration can reduce transaction costs for 
exchange partners through enhancing information processing capabilities and thus influence interorganizational governance structures (Jean, Sinkovics and Kim 2010). Because all joint actions between channel partners are information-intensive activities, online IT integration can increase information visibility within supply chain relationships and thus improve all relevant cooperativeness activities (Kim, Cavusgil and Calantone 2006; Wang, Tai and Wei 2006). Moreover, drawing from transaction cost economics (TCE), Kim and Mahoney (2006) proposed that IT integration could enhance mutual commitment between exchange parties and thus facilitate relational governance in relationships. Some recent studies also offer empirical evidence which demonstrates that IT integration through B2B technology can increase cooperativeness and collaborative activities in supply chain relationships (Kim, Cavusgil and Calantone 2005; Kim and Umanath 2005; Sanders 2007).

However, some scholars also pointed out that IT integration could be also detrimental to relationship development due to the effects of impersonal communications (Yamin and Sinkovics 2006). Further, some strategic levels of cooperativeness efforts such as new product development with suppliers require intensive face to face interactions between both parties (Sanders 2008; Yamin and Sinkovics 2007, 2010). In global supply chain relationships, we argue that IT integration can enhance cooperativeness efforts because the advancement of B2B technology can provide timely cross-border communications and interactions between channel members and thus significantly reduce cooperativeness cost (Jean and Sinkovics 2010; Jean, Sinkovics and Cavusgil 2010). Thus,

Hypothesis 1a: The higher the IT integration between MNEs and their local suppliers, the greater the cooperativeness efforts in international supply chain relationships.

On the contrary, there has been limited literature which addresses the relationships between IT integration and control in interfirm relationships. This could be the reason that IT integration is still new in the interorganizational governance literature while previous literature has neglected monitoring or control as a governance mechanism (Heide, Wathne and Rokkan 2007). IT integration through Internet can provide timely information processing capabilities for firms and increase their ability to access data from partners with regard to evaluating suppliers' performance metrics (Birnberg 1998). For example, Dell computer has adopted an Internet B2B system to integrate the company's international subcontractors in order to provide them with daily inventory or ordering information in supply chain relationships. Thus, we predict:

Hypothesis 1b: The higher the IT integration between MNEs and their local suppliers, 
the greater the MNEs' use of control in international supply chain relationships.

\section{The relationships between trust and governance mechanisms}

In this study, we define trust as the confidence that exchange partners have for each other in terms of benevolence and credibility (Doney and Cannon 1997; Wu et al. 2007). Trust has been extensively studied in the business-to business relationship literature (e.g. Morgan and Hunt 1994). Trust is believed to be critical as it is seen to facilitate more open communication, information sharing (Zand 1972), cooperation (Anderson and Narus 1990) and strategic flexibility (Handfield and Bechtel 2002). Trust has been proposed to reduce transaction costs in interfirm relationships. It has also been treated as an effective tool for partners to govern their relationship, particularly in international channel relationships (Cavusgil, Deligonul and Zhang 2004; Wu et al. 2007). It is also acknowledged that trust may be a critical factor in enhancing business performance and could be a source of sustainable competitive advantage (Wu et al. 2006; Zhang, Cavusgil and Roath 2003).

Some studies have linked trust with cooperativeness efforts in interfirm relationships (Jap 1999). Trust shows a signal of good faith that the other party will not behave opportunistically and provides the foundation of cooperative activities in pursuit of mutual benefits in interfirm relationships. Moreover, in trustworthy business relationships, firms will be more willing to perform the necessary tasks and focus on resource utilization in the relationships. Thus, we predict:

Hypothesis 2a: The higher the trust between MNEs and their local suppliers, the greater the cooperativeness efforts in international supply chain relationships.

With regards to the relationships between trust and vertical control, some researchers draw from TCE and proposed that trust can substitute and reduce the use of control in relationship management because trust provides a foundations of mutual belief and a confidence of future intention (Zaheer and Venkatraman 1995). However, empirical evidence on this issue has been mixed. Zaheer and Venkatraman (1995) argue that trust reduces the level of quasi-integration but they not find empirical support. A recent study by Ryu, Min and Zushi (2008) in the context of manufacturer-supplier relationships points out that under high environmental uncertainty, trust can effectively reduce manufacturer's use of control over its suppliers.

On the other hand, some also argue that trust can reduce the level of resistance while providing harmony to the controller-controlee relationship (Das and Teng 2001). Thus, 
control can work better with the presence of certain levels of trust. However, empirical evidence on this relationship has been limited. It is difficult to develop trust in the relationship in asymmetric relationships between MNEs and their local suppliers due to different distances within international exchange relationships (Cavusgil, Deligonul and Zhang 2004). Therefore, if trust has been established between exchange parties, MNEs will be more willing to relinquish their control over suppliers due to the intrusive nature of control. Thus, we argue

Hypothesis 2b: The higher the trust between MNEs and their local suppliers, the lower the MNEs' use of control over their local suppliers in international supply chain relationships.

\section{The relationships between IT integration and trust}

The relationships between trust and IT integration through Internet and B2B technology have not been well understood in the extant literature. Some researchers argue that trust in the relationships can facilitate the adoption of B2B technology because it reduces the perceived risk of being "locked-in" when adopting transactional specific investments. However, empirical evidence is mixed. For example, Ryssel et al. (2004) propose that trust enhanced the adoption of shared IT systems in business relationships, but empirical results were not supported.

On the other hand, some studies also propose that IT integration can facilitate trust building because the reciprocal transactional investment nature of IT integration through Internet and B2B technology. As Kim and Mathoney (2006) point out that IT integration can be seen as a relationship specific IT system which can build mutual commitment to support transactions for exchange parties in the relationships. IT integration can facilitate timely information exchange and increase mutual understandings for exchange parties and thus provide a signal and good atmosphere for long term relationships development. Hence, this leads us to propose that

Hypothesis 3: The higher the IT integration between MNEs and their local suppliers, the greater the trust in international supply chain relationships.

\section{The relationship between governance mechanism and supplier responsiveness}

Traditional TCE approaches mainly focus on the economic aspects of governance mechanisms concerning reducing opportunism in buyer-supplier relationships. Recent studies have started to investigate the role of value creation in different governance mechanisms (e.g. Wu et al. 2007). Drawing from resource based view (RBV), Dyer and Singh (1998) identified effective governance mechanisms as one of the sources of competitive advantage in 
interorganizational relationships. Consistent with this logic, this paper argues that effective governance including cooperativeness efforts and vertical control within international supply chain relationships can enhance supplier responsiveness: one focal performance variable in global supply chain management.

Some studies have shown that governance and relationships structures can affect supplier responsiveness in supply chain relationships. Hult et al. (2004) find that knowledge development within supply chain partners can enhance cycle time performance. As MNEs and their suppliers strive to produce mutually cooperativeness efforts, suppliers in the supply chain relationships become more educated about know how to efficiently operate their valueadding activities. Hence, they can respond to their customer's needs and preferences more quickly. Moreover, cooperativeness efforts in supply chain relationships can create a platform for joint problem-solving typically consisting of routines and processes between exchange parties that can be flexible and adjustable when facing certain problems. Thus, we predict that:

Hypothesis 4: The higher the cooperativeness efforts between MNEs and their local suppliers, the greater the supplier responsiveness in international supply chain relationships.

Ideas from innovation network provide the basis for predicting the link between control and supplier responsiveness. As orchestrator, it has been argued that hub firm should enhance network innovation by providing certain leadership to reduce uncertainty (Dhanaraj and Parkhe 2006). Similarly, the MNE, as orchestrator in global supply chain, can use control to constantly review suppliers' performance metrics to provide proper guidance in order to reduce errors and ensure supplier's responsiveness. Performance control also demonstrates MNE's relinquishment of certain authority and thus gives suppliers more autonomy which can lead them to be more responsive and innovative (Carson 2007). Thus, we predict that:

Hypothesis 5: The higher the control between MNEs and their local suppliers, the greater the supplier responsiveness in international supply chain relationships.

The moderating effect of cultural distance on the impact of IT integration and trust on governance mechanisms

Some studies have tried to look into the contextual effect of the impact of IT integration and trust on interfirm governance mechanism. Culture distance between exchange parties has been argued to influence governance mechanisms in international channel relationships (Zhang, Cavusgil and Roath 2003). However, only limited empirical research 
has been conducted to examine this relationship. Highly culturally diverse environment creates additional communication and cooperativeness cost for exchange partners in international supply chain relationships. The advanced IT can enhance information processing capabilities for the firms and thus has been able to better govern exchange relationships under high cultural distance context (Jean, Sinkovics and Kim 2010). On the other hand, trust, which can reduce transaction cost between exchanges partners across borders, has been regarded as an effective governance enabler in international channel relationships. Thus, the effect of trust on enhancing governance mechanisms is expected to be stronger under higher cultural distance context. In all, we predict:

Hypothesis 6: The higher the cultural distance between MNEs and their local suppliers, the greater the impact of trust and IT integration on cooperativeness and control in international supply chain relationships.

\section{Methodology}

\section{Empirical context and data collection}

The empirical context of this paper is constituted by the international business-tobusiness relationship between Taiwanese OEM/ODM suppliers and their international MNE buyers in the electronics industry. The relationship is an international subcontracting relationship. Our focus is on a particular OEM/ODM supplier's action, i.e. responsiveness, to the exchange relationships with their MNEs customers, especially with regard to MNE's governance strategy including cooperativeness efforts, control, trust and IT integration. We deliberately focus on the electronics industry in Taiwan as an empirical context because members in electronics industry are firms that have pioneered the development of information technology and made great IT investments in supply chain management. Moreover, the structure of the ODM/ODM electronics supplying network is characterized by significant asymmetric bargaining relationships between MNEs and their local suppliers.

We collected data through a cross-sectional survey. The sampling frame for the survey comprised of all electronic companies from the year 2007 directory of the Top 5000 Largest Firms in Taiwan, published by China Credit Information Service Ltd (a total of 1069 companies). The sample frame covered a range of electronics companies including communication products, semiconductors, computer components and peripherals and so on. All firms were contacted to assess their eligibility and locate appropriate informants for the study.

Data was obtained through a key informant technique, which is consistent with prior 
studies on interorganizational issues (Kumar, Scheer and Steenkamp 1995). The key informants in this study are senior account managers, marketing managers who are in charge of maintaining relationship with MNE customers and had certain knowledge about IT investment in supply chain relationships. We also assessed their familiarity with the questions through the data collection instrument.

The survey was conducted in two waves. Four weeks after the first mailing of questionnaires and introductory letter, reminder letters and questionnaires were sent out to non respondents. As result, 219 useable questionnaires were received for a response rate of $20 \%$.

Nonresponse bias was assessed by a comparison of; (1) sample statistics to known values of values of the population, such as annual sales volume and number of employees, and (2) first and second wave data (Armstrong and Overton 1977). Neither procedure revealed significant different between sampled and target populations. Some descriptive results of the respondents are shown in

Table 1.

Insert

Table 1 about here

\section{Questionnaire development and measures}

Since global supply chain management research is relatively new, theory is still being developed (Samiee 2008). Therefore, to create the survey items, 15 in-depth interviews were conducted with 15 senior OEM/DOM account managers or directors. In order to balance the dyadic point of view in international subcontracting, we also conducted 2 interviews with branded electronics MNE buyers. These interviews, together with an extensive review of the literature, were used to develop the questionnaire.

Overall, all constructs in the model were measured with multiple-item reflective scales. In general, well-validated measures reported in previous top marketing, international business and strategic management journal were used. We also follow Churchill's (1979) multiple-steps and multi-validation methods to modify and develop the items for key construct in the conceptual framework. For all scales, each item was measured using a 7-point Likert scale $(7=$ strongly agree, $1=$ strongly disagree $)$.

As shown in 
Table 2, IT integration was measured by five items, building on the work of Wang et al. (2006) and adapted to the cross-border context in the study. A four-item scale was used to measure trust. It was taken from Doney and Cannon (1997) and adapted to our context. We derived the four items from those that Kumar et al.(1995) and Ryu et al. (2007) used and adapted them to our context. Cooperativeness efforts was measured by three item scale assessing MNEs and their suppliers goal to produce mutually beneficial strategic outcomes .The items were adapted from Jap's (1999) work. Vertical control was measured by three items which assess MNE's use of different monitoring of supplier's different performance. The items were adapted from the ones used by Stump and Heide (1996). Finally, supplier's responsiveness was measured by five items which modified from Kim et al (2006) and Handfield and Bechtel's (2002) work. The items were used to capture suppliers' capability to quickly respond's to their MNE customers' need.

As all measures in this study were collected via a single questionnaire, we checked for the possibility of common method bias. Harman's one-factor test was used to approach this issue (Podsakoff and Organ 1986). A principal component analysis of all items included in this study did not reveal a dominant factor (the first factor explains only $17 \%$ of the total variance), to this end this - simple - check for the presence of common method bias did not reveal evidence of common method bias in this study.

\section{Reliability and validity}

A confirmatory factor analysis was carried out to investigate the convergent and discriminant discriminant validity of each construct in the proposed conceptual model (Bentler 2005). The measurement model including all constructs was fitted by the estimated procedure of the EQS program (Bentler 2005). The results of the analysis are shown in 
Table 2. The model provides a good fit given the complex nature of the second-order confirmatory factor analysis (CHI-SQUARE $=282.866$ with degree of freedom (d.f.) $=137$; $\mathrm{CFI}=0.945 ; \mathrm{NFI}=0.945 ; \mathrm{NNFI}=0.931 ; \mathrm{RMSEA}=0.071)$. Moreover, all items loaded on their respective constructs are statistically significant. Further, the composite reliability for all constructs was above the 0.7 level (shown in 
Table 2.) suggested by Hair (2006), indicating adequate reliability for each construct. Moreover, all factors loadings were statistically significant at the 5\% level, and all of the the factor loadings exceed the arbitrary 0.5 standard (Fornell and Larcker 1981), as shown in 
Table 2. Thus, these measures demonstrate adequate convergent validity. In terms of discriminant validity, this study assessed the discriminant validity of each construct in two ways (Wu et al. 2007). First, a procedure recommended by Bagozzi, Yi and Phillips (1991) was adopted. We examined pairs of related constructs in a two-factor CFA, once constraining the correlations between two constructs to unity and once freeing this parameter. Then a chisquare difference test was conducted. The results indicated that the chi-square values were significantly lower for the unstrained models at the 5\% level, which suggest that the constructs exhibit discriminant validity. This study also checked the methods suggested by Fornell and Larcker (1981). As shown in 
Table 3 , the square root of the average variance extracted is greater that all corresponding correlations, which indicates adequate discriminant validity.

Insert 
Sinkovics / Jean / Roath / Cavusgil

Table 2 about here

Insert

Page 18 of 26 
Table 3 about here

\section{Structural model test results}

Error! Reference source not found. presents results of the structural tested evaluating overall model fit. The overall fit statistics indicate a very good fit for the full model (Chi-square:308.525, df=145, NNFI:0.927, NFI:0.938, CFI:0.938, RMSEA:0.073). Regarding the hypothesis relationships, unlike the claim of Hypothesis 1a, IT integration does not enhance cooperativeness efforts directly $(, \mathrm{P}>0.1)$. Thus the positive relationship suggests that Hypothesis 1a is not supported. The path coefficient from IT integration to supplier control $\mathrm{s}$ is $0.239(\mathrm{t}=3.163 ; \mathrm{p}<0.01)$, which supports Hypothesis $1 \mathrm{~b}$. The path coefficient from trust to cooperativeness efforts is $0.768(\mathrm{t}=3.163, \mathrm{p}<0.01)$. Thus, Hypothesis $2 \mathrm{a}$ is supported. The path coefficient from trust to control is $0.219(\mathrm{t}=2.978, \mathrm{p}<0.01)$, which not support but against Hypothesis $2 \mathrm{~b}$, which posits a negative relationships between trust and MNEs' control in international supply chain relationships. We tested a positive effect of IT integration on trust with hypothesis 3 . According to the result, IT integration facilitates trust in international supply chain relationships $(\mathrm{P}<0.01)$, as expected in Hypothesis 3 . Hypothesis 4 and 5 relate interorganizational governance mechanisms to supplier responsiveness. We found the direct impact from cooperativeness efforts to supplier responsiveness is significant (coefficient $=0.626(\mathrm{t}=6.716, \mathrm{p}<0.01)$. Therefore, in accordance with what is expressed in Hypothesis 4 . The path coefficient from MNE's use of control to supplier responsiveness is 0.167 ( $\mathrm{t}=2.547$, $\mathrm{p}<0.01$ ), which supports Hypothesis 5.

The moderating influence of cultural distance on the effect of IT integration and trust on on governance mechanisms (i.e. cooperativeness efforts and control) was assessed by a twogroup analysis with EQS. The Chi-square difference indicated that cultural distance moderate the effect of trust on control significantly, with a Chi-square difference of $5.956(\mathrm{p}<0.05)$. Therefore, Hypothesis 6 is partially supported. Table 5 reports the results of two-group analysis. All the summary of hypotheses test results was shown in

Table 4.

Insert

Table 4 about here 
Insert Table 5 about here

Insert Error! Reference source not found. about here

\section{Discussion and implications}

Although the issues on cooperativeness, control and responsiveness in the context of MNEs and subsidiaries are well conceptualized and empirically verified, their interrelationships in the context of MNEs' global supply chain relationships have received little conceptual and empirical attention. In order to seek a better understanding of how MNEs can enhance local suppliers' responsiveness in cross-border supply chain relationships, we draw on RBV and TCE, and develop a framework for IT integration, trust, cooperativeness efforts, MNE's use of control, and supplier responsiveness between MNEs and their local suppliers. Moreover, we also assess the moderating effect of cultural distance on the process between IT integration and trust on cooperativeness and control. The model is tested using data collected from Taiwanese electronics suppliers in relationships with MNE customers. The results support most hypotheses but fail to support the link between IT integration and cooperativeness. Moreover, the moderating effect of cultural distance on the effect of trust and IT integration on governance mechanisms was partially supported. The findings indicate that both IT integration and trust can facilitate suppliers' responsiveness in international supply chain relationships but through different and indirect mechanism and processes. Based on the findings, a number of guidelines can be offered to both scholars and practitioners regarding the theoretical and managerial implications.

First, we postulated that IT integration will facilitate both cooperativeness and MNE's control in international supply chain relationships. However, it appears that IT integration does not facilitate cooperativeness efforts directly, as Hypothesis 1a was not supported. IT integration only impacts cooperativeness efforts through the mediating effect of trust. This explanation is offered by the mixed empirical results on the link between IT integration through IT and cooperativeness in channel relationships. For example, Sanders (2008) finds 
that IT use for exploitation does not enhance strategic cooperativeness in supply chain relationships. She argued that strategic cooperativeness still requires face to face communication and cannot be fully replaced by advanced IT. Another possible explanation is drawing from TCE which argues that IT integration through IT, relational specific investments can create a potential "lock-in" risk for small suppliers in asymmetric relationships with MNEs and thus loses supplier's willing to coordinate well with their MNE customers.

On the contrary, we find that IT integration can enhance MNE's use of control in international supply chain relationships. Although some researchers propose that IT can facilitate firm's monitoring and control capability (Subramani 2004), empirical evidence is very limited. This study provides empirical evidence which shows IT integration can provide timely information exchange and thus enhance MNE's capability in monitoring supplier's performance metrics in international supply chain relationships.

The empirical findings also suggest that trust plays an important role; trust mediates the influence of IT integration on cooperativeness efforts. Although some anecdotal evidence point to the impact of IT on trust in interfirm relationships, empirical studies on this issue are still limited. The finding in this paper shows that IT integration through B2B information systems can create a signal for mutual commitment in supporting exchange and thus enhance trust in international supply chain relationships.

Regarding relationships between trust and the two governance mechanisms which include cooperativeness efforts and control, this study finds that trust strongly enhances cooperativeness efforts. This finding is consistent with the arguments that trust serves as a foundation of relational governance mechanism (Jap 1999). Moreover, this study also demonstrates that trust can facilitate MNE's use of control against their local suppliers. Yet, some studies argue that firms would loosen up control when high levels of trust exist in exchange relationships (Stump and Heide 1996). However, other scholars propose that trust can also expose firms' vulnerable to their partners and can raise the level of control in business relationships (Ryu, Min and Zushi 2008). This study provides empirical evidence to resolve this debate and shows that MNEs tend to exercise more control over their local suppliers despite certain levels of trust existing within the context of international exchange relationships. One plausible explanation is that trust reduces resistance and brings harmony to the relationships between MNEs and their local suppliers (Das and Teng 2001). Accordingly, control, as a unilateral governance mechanism, works better for MNEs with the presence of 
trust in exchange relationships with their local suppliers. More specifically, drawing from the results of our moderating effect test, when MNEs face higher cultural distance suppliers in international supply chain relationships, trust plays more supplementary role for MNEs to gain more control over their local suppliers.

Finally, this study shows that both cooperativeness and MNEs' use of control can enhance local suppliers' responsiveness. The findings are consistent with the emerging view of RBV which argues that effective governance mechanisms can be sources of firms' competitive advantage in interorganizational relationships (Dyer and Singh 1998; Jap 1999). Cooperativeness efforts can enhance mutual understanding and enable suppliers to be more responsive to environmental changes. On the other hand, MNEs' control over their local suppliers can reduce goal incongruence through goal setting and thus enhance supplier's responsiveness.

\section{Managerial implications}

The nature of global competition has shifted from company vs. company to supply chains vs. supply chain. Global supply chain management has received great attention from managers recently who have acknowledged the need to develop capabilities which enable the supply chain's role as a competitive weapon in the drive to achieve competitive advantage.

Supply chain responsiveness, the key metric for accessing supply chain functioning, is central to a firm's success. This study shows that both IT integration through IT and trust between MNEs and their local suppliers can enhance responsiveness in global supply chain.

This study also reveals that trust and IT integration enhance suppliers' responsiveness through different mechanisms. On the one hand, IT integration does not lead to higher cooperativeness in global supply chain relationships. Instead IT integration only enhances supplier responsiveness through enhancing MNEs' control capability. On the other hand, trust in supply chain relationships plays a crucial role in enhancing cooperativeness efforts and ultimately leads to higher responsiveness. These results suggest that IT integration should be accompanied by trust in structuring global supply chain relationships. Managers should not only pursue better IT integration with channel partners but also need to continue developing trustworthy supply chain relationships.

The study findings also suggest that IT integration through IT serve as a cornerstone of trust building. IT integration could be seen as a relationship-specific investment which enhances mutual commitment to support exchange in global supply chain relationships. 


\section{Limitations and future research}

Despite rich implications, several limitations of this study should be acknowledged. First, this study only adopted one perspective of dyad data from a supplier's perspective in international supply chain relationships. This raised a potential bias. Future research may also examine our proposed model from MNE buyers' perspectives. Second, this study was based only on cross-sectional data. Thus a longitudinal data should also need to be examined in the future research and can provide more insights on the dynamic nature of how IT and trust can enhance responsiveness in the international channel relationships. Moreover, this study only examines trust and IT integration as antecedents of suppliers' responsiveness. Other potential relationship variables as antecedents of suppliers' responsiveness such as contracts or dependence (Handfield and Bechtel 2002) should be examined in the future.

\section{References}

Anderson, J. C., \& Narus, J. A. (1990). A model of distributor firm and manufacturer firm working partnerships. Journal of Marketing, 54(1), 42-58.

Armstrong, J. S., \& Overton, T. S. (1977). Estimating nonresponse bias in mail surveys. Journal of Marketing Research, 14(3), 396-402.

Aulakh, P. S., Kotabe, M., \& Sahay, A. (1996). Trust and performance in cross-border marketing partnerships: A behavioral approach. Journal of International Business Studies, 27(5), 1005-1032.

Bagozzi, R. P., Yi, Y., \& Phillips, L. W. (1991). Assessing construct validity in organizational research. Administrative Science Quarterly, 36(3), 421-458.

Barney, J. (1991). Firm resources and sustained competitive advantage. Journal of Management, 17(1), 99-120.

Bello, D. C., \& Gilliland, D. I. (1997). The effect of output controls, process controls, and flexibility on export channel performance. Journal of Marketing, 61(1), 22-38.

Bentler, P. M. (2005). EQS 6 structural equations program manual. Encino, CA: Multivariate Software Inc.

Birnberg, J. G. (1998). Control in interfirm co-operative relationships. Journal of Management Studies, 35(4), 421-428.

Buckley, P. J., \& Ghauri, P. N. (2004). Globalisation, economic geography and the strategy of multinational enterprises. Journal of International Business Studies, 35(2), 81-98.

Carson, S. J. (2007). When to give up control of outsourced new product development. Journal of Marketing, 71(1), 49-66.

Cavusgil, S. T., Deligonul, S., \& Zhang, C. (2004). Curbing foreign distributor opportunism: An examination of trust, contracts, and the legal environment in international channel relationships. Journal of International Marketing, 12(2), 7-27.

Celly, K. S., \& Frazier, G. L. (1996). Outcome-based and behavior-based coordination efforts in channel relationships. Journal of Marketing Research, 33(2), 200-210.

Churchill, G. A. (1979). A paradigm for developing better measures of marketing constructs. Journal of Marketing Research, 16(1), 64-73.

Cray, D. (1984). Control and coordination in multinational corporations. Journal of 
International Business Studies, 15(2), 85-98.

Das, T. K., \& Teng, B.-S. (2001). Trust, control, and risk in strategic alliances: An integrated framework. Organization Studies, 22(2), 251-283.

Dhanaraj, C., \& Parkhe, A. (2006). Orchestrating innovation networks. Academy of Management Review, 31(3), 659-669.

Doney, P. M., \& Cannon, J. P. (1997). An examination of the nature of trust in buyer-seller relationships. Journal of Marketing, 61(2), 35-51.

Dyer, J. H., \& Singh, H. (1998). The relational view: Cooperative strategy and sources of interorganizational competitive advantage. Academy of Management Review, 23(4), 660-679.

Fornell, C., \& Larcker, D. F. (1981). Structural equation models with unobservable variables and measurement error: Algebra and statistics. Journal of Marketing Research, 18(3), 382-388.

Ghosh, M., \& John, G. (1999). Governance value analysis and marketing strategy. Journal of Marketing, 63(4), 131-145.

Hair, J. F., Black, W. C., Babin, B. J., Anderson, R. E., \& Tatham, R. L. (2006). Multivariate data analysis (6th ed.). Upper Saddle River, NJ: Prentice-Hall.

Handfield, R. B., \& Bechtel, C. (2002). The role of trust and relationship structure in improving supply chain responsiveness. Industrial Marketing Management, 31(4), 367-382.

Heide, J. B. (1994). Interorganizational governance in marketing channels. Journal of Marketing, 58(1), 71-85.

Heide, J. B., Wathne, K. H., \& Rokkan, A. I. (2007). Interfirm monitoring, social contracts, and relationship outcomes. Journal of Marketing Research, 44(3), 425-433.

Hult, G. T. M., Ketchen, D. J., \& Arrfelt, M. (2007). Strategic supply chain management: Improving performance through a culture of competitiveness and knowledge development. Strategic Management Journal, 28(10), 1035-1052.

Hult, G. T. M., Ketchen, D. J., \& Slater, S. F. (2004). Information processing, knowledge development, and strategic supply chain performance. Academy of Management Journal, 47(2), 241-253.

Jap, S. D. (1999). Pie-expansion efforts: Collaboration processes in buyer-supplier relationships. Journal of Marketing Research, 36(4), 461-475.

Jean, R.-J. B. (2007). The ambiguous relationship of ICT and organizational performance: A literature review. Critical Perspectives on International Business, 3(4), 306-321.

Jean, R.-J. B., \& Sinkovics, R. R. (2010). Relationship learning and performance enhancement via advanced information technology: The case of Taiwanese dragon electronics firms. International Marketing Review, 27(2), 200-222.

Jean, R.-J. B., Sinkovics, R. R., \& Cavusgil, S. T. (2010). Enhancing international customersupplier relationships through IT resources: A study of Taiwanese electronics suppliers. Journal of International Business Studies, 41(7), 1218-1239.

Jean, R.-J. B., Sinkovics, R. R., \& Kim, D. (2008). Information technology and organizational performance within international business to business relationships: A review and an integrated conceptual framework. International Marketing Review, 25(5), 563-583.

Jean, R.-J. B., Sinkovics, R. R., \& Kim, D. (2010). Drivers and performance outcomes of relationship learning for suppliers in cross-border customer-supplier relationships: The role of communication culture. Journal of International Marketing, 18(1), 63-85.

Kim, D., Cavusgil, S. T., \& Calantone, R. J. (2005). The role of information technology in supply-chain relationships: Does partner criticality matter? The Journal of Business \& Industrial Marketing, 20(4/5), 169-178.

Kim, D., Cavusgil, S. T., \& Calantone, R. J. (2006). Information system innovations and 
supply chain management: Channel relationships and firm performance. Journal of the Academy of Marketing Science, 34(1), 40-54.

Kim, K. K., \& Umanath, N. S. (2005). Information transfer in B2B procurement: An empirical analysis and measurement. Information \& Management, 42(6), 813-828.

Kim, S. M., \& Mahoney, J. T. (2006). Mutual commitment to support exchange: Relationspecific it system as a substitute for managerial hierarchy. Strategic Management Journal, 27(5), 401-423.

Kumar, N., Scheer, L. K., \& Steenkamp, J.-B. E. M. (1995). The effects of perceived interdependence on dealer attitudes. Journal of Marketing Research 32(3), 348-356.

Luo, Y., Liu, Y., Zhang, L., \& Huang, Y. (2010). A taxonomy of control mechanisms and effects on channel cooperation in China. Journal of the Academy of Marketing Science, in press(doi: 10.1007/s11747-010-0198-1)

Lusch, R. F., \& Brown, J. R. (1996). Interdependency, contracting, and relational behavior in marketing channels. Journal of Marketing, 60(4), 19-38.

Morgan, R. M., \& Hunt, S. D. (1994). The commitment-trust theory of relationship marketing. Journal of Marketing, 58(3), 20-38.

Ouchi, W. G. (1980). Markets, bureaucracies, and clans. Administrative Science Quarterly, 25(1), 129-141.

Podsakoff, P. M., \& Organ, D. W. (1986). Self-reports in organizational research: Problems and prospects. Journal of Management, 12(4), 531-544.

Ryssel, R., Ritter, T., \& Gemünden, H. G. (2004). The impact of information technology deployment on trust, commitment and value creation in business relationships. The Journal of Business \& Industrial Marketing, 19(3), 197-207.

Ryu, S., \& Eyuboglu, N. (2007). The environment and its impact on satisfaction with supplier performance: An investigation of the mediating effects of control mechanisms from the perspective of the manufacturer in the U.S.A. Industrial Marketing Management, 36(4), 458-469.

Ryu, S., Min, S., \& Zushi, N. (2008). The moderating role of trust in manufacturer-supplier relationships. Journal of Business \& Industrial Marketing, 23(1), 48-58.

Samiee, S. (2008). Global marketing effectiveness via alliances and electronic commerce in business-to-business markets. Industrial Marketing Management, 37(1), 3-8.

Sanders, N. R. (2007). An empirical study of the impact of e-business technologies on organizational collaboration and performance. Journal of Operations Management, 25(6), 1332-1347.

Sanders, N. R. (2008). Pattern of information technology use: The impact on buyer-supplier coordination and performance. Journal of Operations Management, 26(3), 349-367.

Song, M., Di Benedetto, C. A., \& Zhao, Y. (2008). The antecedents and consequences of manufacturer-distributor cooperation: An empirical test in the u.S. And Japan. Journal of the Academy of Marketing Science, 36(2), 215-233.

Stump, R. L., \& Heide, J. B. (1996). Controlling supplier opportunism in industrial relationships. Journal of Marketing Research, 33(4), 431-441.

Subramani, M. (2004). How do suppliers benefit from information technology use in supply chain relationships? MIS Quarterly, 28(1), 45-73.

Wang, E. T. G., \& Hsiao-Lan, W. (2007). Interorganizational governance value creation: Coordinating for information visibility and flexibility in supply chains. Decision Sciences, 38(4), 647-674.

Wang, E. T. G., Tai, J. C. F., \& Wei, H.-L. (2006). A virtual integration theory of improved supply-chain performance. Journal of Management Information Systems, 23(2), 41-64.

Weitz, B. A., \& Jap, S. D. (1995). Relationship marketing and distribution channels. Journal of the Academy of Marketing Science, 23(4), 305-320. 
Williamson, O. E. (1975). Markets and hierarchies: Analysis and antitrust implications. New York: Free Press.

Wu, F., Sinkovics, R. R., Cavusgil, S. T., \& Roath, A. S. (2007). Overcoming export manufacturer's dilemma in international expansion. Journal of International Business Studies, 38(2), 283-302.

Wu, F., Yeniyurt, S., Kim, D., \& Cavusgil, S. T. (2006). The impact of information technology on supply chain capabilities and firm performance: A resource-based view. Industrial Marketing Management, 35(4), 493-504.

Yamin, M., \& Sinkovics, R. R. (2006). Online internationalisation, psychic distance reduction and the virtuality trap. International Business Review, 15(4), 339-360.

Yamin, M., \& Sinkovics, R. R. (2007). ICT and MNE reorganisation: The paradox of control. Critical Perspectives on International Business, 3(4), 322-336.

Yamin, M., \& Sinkovics, R. R. (2010). ICT deployment and resource-based power in multinational enterprises. Futures, 42(9), 952-959.

Zaheer, A., \& Venkatraman, N. (1995). Relational governance as an interorganizational strategy: An empirical test of the role of trust in economic exchange. Strategic Management Journal, 16(5), 373-393.

Zand, D. E. (1972). Trust and managerial problem solving. Administrative Science Quarterly, 17(2), 229-239.

Zhang, C., Cavusgil, S. T., \& Roath, A. S. (2003). Manufacturer governance of foreign distributor relationships: Do relational norms enhance competitiveness in the export market? Journal of International Business Studies, 34(6), 550-566.

\section{Appendix - Tables and figures}

Figure 1: Conceptual framework

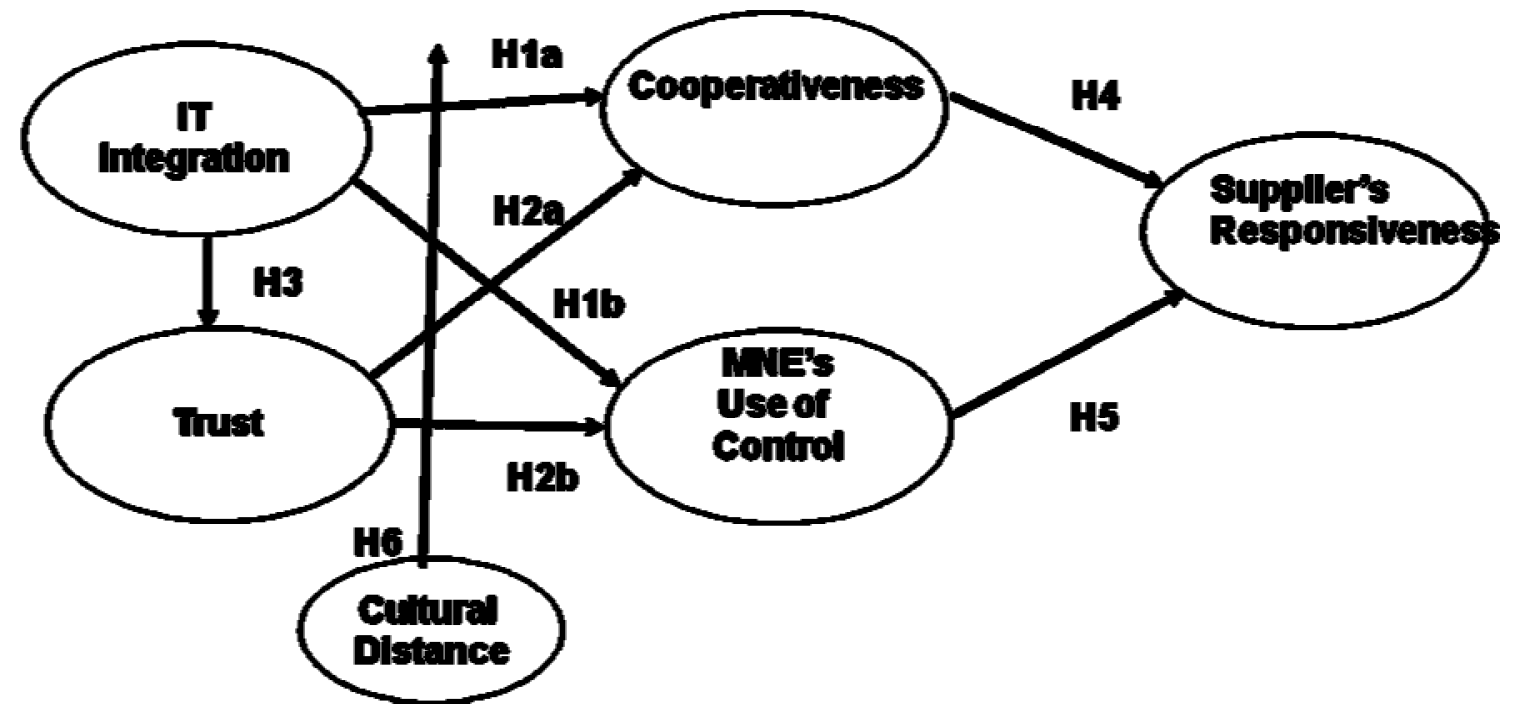


Table 1: Characteristics of responding firms

\begin{tabular}{|c|c|c|c|}
\hline Product Distribution & Percentage & Sales Revenue & \\
\hline Communication Products & $12.2 \%$ & NT100M-NT500M (US \$3M) & $19.1 \%$ \\
\hline Systems & $6.5 \%$ & NT501-NT1B & $15.9 \%$ \\
\hline Computer Peripherals & $14.2 \%$ & NT1B-NT5B & $39.0 \%$ \\
\hline Optoelectronics & $14.6 \%$ & NT5B-NT10B & $7.3 \%$ \\
\hline Semiconductors & $15.9 \%$ & More than NT10B (US \$300M) & $18.7 \%$ \\
\hline Computer Components & $36.6 \%$ & Total & $100 \%$ \\
\hline Total & $100 \%$ & $\begin{array}{l}\text { Length of } \\
\text { International partnerships }\end{array}$ & \\
\hline Employee Numbers & & Less than 1 year & $4.5 \%$ \\
\hline Less than 100 & $20.3 \%$ & $1-2$ years & $8.9 \%$ \\
\hline $100-199$ & $21.1 \%$ & $3-5$ years & $39 . \%$ \\
\hline $200-499$ & $26.4 \%$ & $6-10$ years & $35 \%$ \\
\hline $500-999$ & $13 \%$ & 11 years and above & $12 \%$ \\
\hline $1000-4999$ & $14.6 \%$ & $\begin{array}{l}\text { Country of origin of international } \\
\text { customers }\end{array}$ & \\
\hline $5000-9999$ & $1.6 \%$ & America & $43.5 \%$ \\
\hline 10000 and above & $2.8 \%$ & Asia & $34.6 \%$ \\
\hline Total & $100 \%$ & Europe & $22.9 \%$ \\
\hline
\end{tabular}


Table 2: Results of CFA

\begin{tabular}{|c|c|c|}
\hline Construct and Measures & $\begin{array}{l}\text { Std. } \\
\text { factor } \\
\text { loadings }\end{array}$ & $\begin{array}{l}\text { Composite } \\
\text { reliability }(\alpha) \\
\text { (Average } \\
\text { Variance } \\
\text { Extraction) }\end{array}$ \\
\hline IT integration & & \multirow[t]{6}{*}{$0.865(0.570)$} \\
\hline $\begin{array}{l}\text { Our international customer accesses or traces our shipping/delivery } \\
\text { schedule electronically. }\end{array}$ & 0.598 & \\
\hline Our international customer monitors our quality of product electronically & 0.680 & \\
\hline $\begin{array}{l}\text { We exchange product price and market information with our international } \\
\text { customer electronically. }\end{array}$ & 0.645 & \\
\hline $\begin{array}{l}\text { We and our international customer coordinate production plans with each } \\
\text { other electronically. }\end{array}$ & 0.899 & \\
\hline $\begin{array}{l}\text { We and our international customer coordinate inventory levels with each } \\
\text { other electronically. }\end{array}$ & 0.897 & \\
\hline Trust & & \multirow[t]{5}{*}{$0.885(0.658)$} \\
\hline We believe the information that our international customer provides us. & 0.765 & \\
\hline $\begin{array}{l}\text { Our international customer is genuinely concerned that our business } \\
\text { succeeds. }\end{array}$ & 0.882 & \\
\hline We trust our international customer keeps our best interests in mind. & 0.765 & \\
\hline Our international customer is trustworthy. & 0.827 & \\
\hline Cooperativeness efforts & & \multirow[t]{4}{*}{$0768(0.530)$} \\
\hline $\begin{array}{l}\text { No matter whether we or our international customer is at fault, problems are } \\
\text { joint responsibility. }\end{array}$ & & \\
\hline $\begin{array}{l}\text { Both we and our international customer are concerned about the other's } \\
\text { profitability. }\end{array}$ & 0.771 & \\
\hline Both companies work together to be successful. & 0.812 & \\
\hline Control & & \multirow[t]{4}{*}{$0.930(0.818)$} \\
\hline This international customer extensively monitors our product quality. & 0.789 & \\
\hline This international customer extensively monitors our delivery timeliness. & 0.978 & \\
\hline This international customer extensively monitors our order fulfillments. & 0.935 & \\
\hline Supplier's responsiveness & & \\
\hline $\begin{array}{l}\text { Compared to our competitors, our supply chain responds more quickly and } \\
\text { effectively to changing major international customer needs. }\end{array}$ & 0.838 & \multirow[t]{4}{*}{$0.893(0.676)$} \\
\hline $\begin{array}{l}\text { Compared to our competitors, our supply chain develops and markets new } \\
\text { products more quickly and effectively. }\end{array}$ & 0.783 & \\
\hline $\begin{array}{l}\text { We have the ability to deal with orders for our international customer in a } \\
\text { short lead time. }\end{array}$ & 0.870 & \\
\hline $\begin{array}{l}\text { We have the ability to be outstanding in on time delivery for our } \\
\text { international customer. }\end{array}$ & 0.794 & \\
\hline \multicolumn{3}{|c|}{$\begin{array}{l}\text { CFA Model - Goodness of Fit Indices: Chi-Square }=282.866 \text { and with degree of freedom }(d . f .)=137 ; \\
\text { Comparative Fit Index }(C F I)=0.945 ; \text { Bollen Fit Index }=0.945 ; \text { Bentler-Bonett Non-Normed Fit } \\
\text { Index }(B B N N F I)=0.931 ; \text { root mean square of approximation }(R M S E A)=0.071 ; 90 \% \\
\text { confidence of RMSEA }(0.059 ; 0.082)\end{array}$} \\
\hline
\end{tabular}


Table 3: Mean, SD, inter-Construct Correlations and Average Variance Extracted $(n=219)$

\begin{tabular}{|l|l|l|l|l|l|l|}
\hline & Mean (S.D.) & (1) & (2) & (3) & (4) & (5) \\
\hline (1) IT integration & $\begin{array}{l}4.560 \\
(1.032)\end{array}$ & $\mathbf{0 . 7 5 4}$ & & & & \\
\hline (2) Trust & $\begin{array}{l}5.560 \\
(1.107)\end{array}$ & $0.254^{* *}$ & $\mathbf{0 . 8 1 1}$ & & & \\
\hline (3) Cooperativeness & $\begin{array}{l}5.236 \\
(0.928)\end{array}$ & $0.229^{* *}$ & $0.754 * *$ & $\mathbf{0 . 7 2 8}$ & & \\
\hline (4)Control & $\begin{array}{l}5.675 \\
(1.124)\end{array}$ & $0.293^{* *}$ & $0.247^{* *}$ & $0.472^{* *}$ & $\mathbf{0 . 9 0 4}$ & \\
\hline (5) Responsiveness & $\begin{array}{l}5.487 \\
(1.026)\end{array}$ & $0.254^{* *}$ & $0.552^{* *}$ & $0.692^{* *}$ & $0.427 * *$ & $\mathbf{0 . 8 2 2}$ \\
\hline
\end{tabular}

Note: Numbers in bold denote the square root of the average Variance extracted (AVE), ${ }^{* *}=p<0.01$

Table 4: Summary of hypothesis test results

\begin{tabular}{|l|l|}
\hline Hypothesis & Results \\
\hline $\begin{array}{l}\text { H1a: The higher the IT integration between MNEs and their local } \\
\text { suppliers, the greater the cooperativeness efforts in international supply } \\
\text { chain relationships. }\end{array}$ & Not supported \\
\hline $\begin{array}{l}\text { H1b: The higher the IT integration between MNEs and their local } \\
\text { suppliers, the greater the MNEs' use of control in international supply } \\
\text { chain relationships. }\end{array}$ & Supported \\
\hline $\begin{array}{l}\text { H2a: The higher the trust between MNEs and their local suppliers, the } \\
\text { greater the cooperativeness efforts in international supply chain } \\
\text { relationships. }\end{array}$ & Supported \\
\hline $\begin{array}{l}\text { H2b: The higher the trust between MNEs and their local suppliers, the } \\
\text { lower the MNEs' use of control over their local suppliers in international } \\
\text { supply chain relationships. }\end{array}$ & Supported \\
\hline $\begin{array}{l}\text { H3: Hypothesis 3: The higher the IT integration between MNEs and their } \\
\text { local suppliers, the greater the trust in international supply chain } \\
\text { relationships. }\end{array}$ & Supported \\
\hline $\begin{array}{l}\text { H4: The higher the cooperativeness efforts between MNEs and their local } \\
\text { suppliers, the greater the supplier responsiveness in international supply } \\
\text { chain relationships. }\end{array}$ & Supported \\
\hline $\begin{array}{l}\text { H5: The higher the control between MNEs and their local suppliers, the } \\
\text { greater the supplier responsiveness in international supply chain } \\
\text { relationships. }\end{array}$ & Supported \\
\hline $\begin{array}{l}\text { H6: The higher the cultural distance between MNEs and their local } \\
\text { suppliers, the greater the impact of trust and IT integration on } \\
\text { cooperativeness and control in international supply chain relationships. }\end{array}$ & $\begin{array}{l}\text { Partially } \\
\text { supported }\end{array}$ \\
\hline
\end{tabular}


Table 5: two-group analysis of the moderating effect of cultural distance

\begin{tabular}{|c|c|c|c|c|c|}
\hline \multirow[t]{2}{*}{ Individual Path } & \multicolumn{2}{|c|}{$\begin{array}{c}\text { Standardized parameter } \\
\text { Estimate }\end{array}$} & \multirow{2}{*}{$\begin{array}{l}\text { Univariate } \\
\text { Chi-square } \\
\text { difference }\end{array}$} & \multirow[t]{2}{*}{$P$-value } & \multirow[t]{2}{*}{ Conclusion } \\
\hline & $\begin{array}{l}\text { Low cultural } \\
\text { distance } \\
\text { group }\end{array}$ & $\begin{array}{l}\text { High cultural } \\
\text { distance } \\
\text { group }\end{array}$ & & & \\
\hline $\begin{array}{l}\text { IT integration } \rightarrow \\
\text { Cooperativeness efforts }\end{array}$ & 0.059 & 0.061 & 0.085 & 0.771 & Not supported \\
\hline IT integration $\rightarrow$ Control & $0.209 * *$ & $0.272 * *$ & 1.328 & .249 & Not supported \\
\hline $\begin{array}{l}\text { Trust } \rightarrow \text { cooperativeness } \\
\text { efforts }\end{array}$ & $.692 * *$ & $.817 * *$ & 0.040 & 0.821 & Not supported \\
\hline Trust $\rightarrow$ Control & $.148^{* *}$ & $.221 * *$ & 5.956 & 0.015 & Supported \\
\hline
\end{tabular}

Figure 2: The structural model

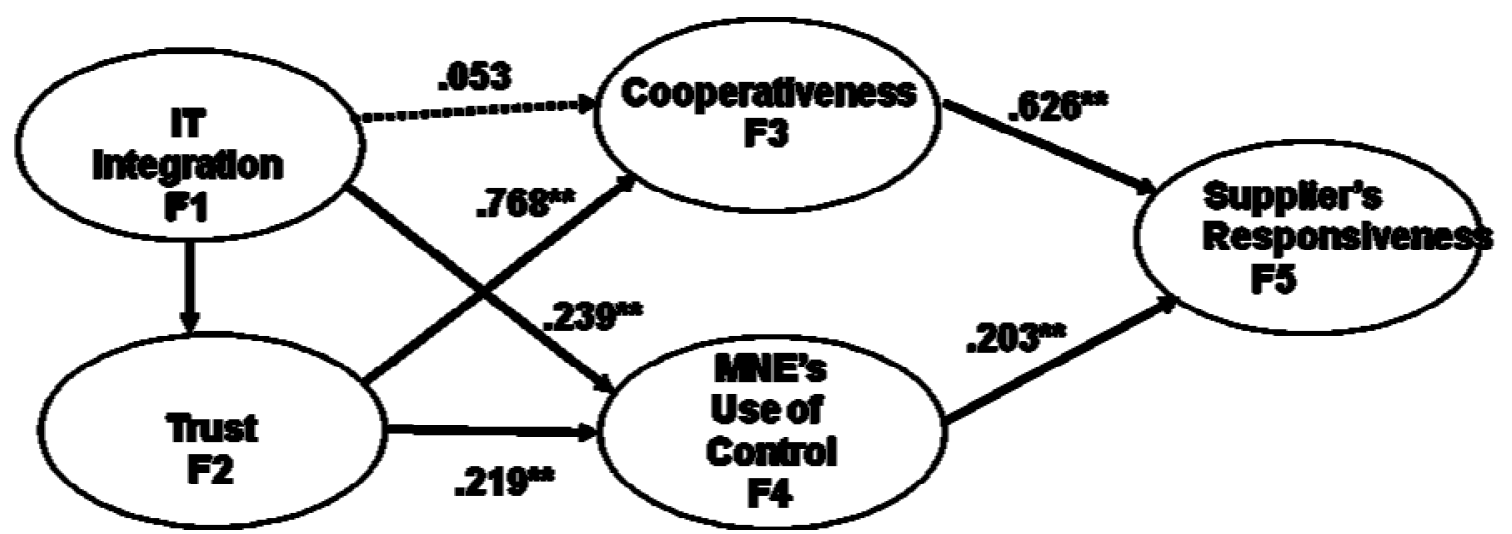

Note: $\quad$ Chi-square:308.525, $d f=145$, NNFI:0.927, NFI:0.938 , CFI:0.938, RMSEA:0.073

$*_{p}<0.05 ; * *^{*}<0.01$, Dashed line indicates insignificant paths. 